ISSN: 1858-4837; E-ISSN: 2598-019X

Volume 15, Nomor 1 (2020),

https://jurnal.uns.ac.id/region

DOI: 10.20961/region.v1511.27064

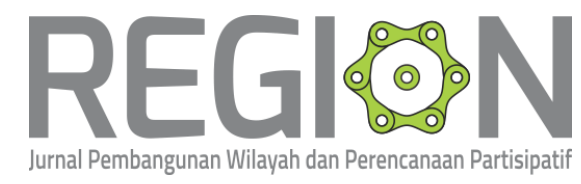

\title{
Potensi dan kendala pengembangan obyek wisata pantai Purwahamba Indah Kabupaten Tegal
}

\author{
Potential and constraints in developing Purwahamba Indah beach tourism \\ objects in Tegal Regency
}

\author{
M H Hidayatulloh ${ }^{1}$, M Viantikasari ${ }^{1}$, A N Bambang ${ }^{2}$, dan Amirudin ${ }^{3}$ \\ ${ }^{1}$ Program Studi Magister Ilmu Lingkungan, Sekolah Pascasarjana, Universitas \\ Diponegoro \\ ${ }^{2}$ Fakultas Perikanan dan Ilmu Kelautan, Universitas Diponegoro \\ ${ }^{3}$ Program Studi Antropologi, Fakultas IImu Budaya, Universitas Diponegoro
}

Corresponding author's email: hidayattulohmohamadheri@gmail.com

\begin{abstract}
Abstrak. Salah satu obyek wisata yang dikenal di Kabupaten Tegal adalah obyek wisata pantai Purwahamba Indah. Obyek wisata ini menjadi salah satu obyek wisata andalan Kabupaten Tegal. Namun dalam beberapa tahun belakangan, tingkat kunjungan wisatawan di obyek wisata pantai Purwahamba Indah tidak mengalami peningkatan yang signifikan. Tujuan penelitian ini adalah mengetahui potensi dan kendala dalam pengembangan kembali obyek wisata pantai Purwahamba Indah. Metode penelitian yang digunakan adalah metode campuran (Mixed Method) dengan strategi eksploratoris sekuensial. Teknik analisis yang digunakan adalah Delphi yang ditunjang dengan analisis deskriptif kualitatif. Hasil studi menunjukan bahwa kendala utama pengembangan obyek wisata Pantai Purwahamba Indah adalah aspek anggaran, masyarakat, dukungan pemerintah dan perencanaan.
\end{abstract}

Kata Kunci: Delphi; Eksploratoris Sekuensial; Obyek Wisata Pantai; Pengembangan Pariwisata; Wisatawan

Abstract. One of the attractions known in Tegal Regency is the Purwahamba Indah
beach tourism object. This tourist attraction is one of the main tourist attractions in
Tegal Regency. But in recent years, the level of tourist visits on the Purwahamba
Indah beach tourism object is less encouraging. The purpose of this study was to
identify potential and constraints in the redevelopment of Purwahamba Indah beach
tourism object. The research method used is the mixed method with a sequential 
exploratory strategy. The analytical technique used is Delphi technique which is supported by qualitative descriptive analysis. The results of the study show that the main obstacles of Purwahamba Indah beach tourism object development are on the budget, community, government support, and planning aspects.

Keywords: Beach Tourism Object; Delphi; Sequential Exploratory; Tourism Development; Tourist

\section{Pendahuluan}

Indonesia memiliki kekayaan alam melimpah yang dapat digunakan sebagai sumber pendapatan negara. Dahulu sektor migas adalah sektor primadona penyumbang devisa negara terbesar sehingga devisa negara sangat bergantung pada sektor ini. Migas termasuk ke dalam sumber daya yang tidak terbarukan sehingga ketersediannya semakin lama semakin habis, maka dari itu ketergantungan kepada migas menjadi permasalahan yang harus diselesaikan secara komprehensif.

Pariwisata merupakan salah satu sektor yang bisa mengganti peran migas sebagai salah satu penggerak ekonomi nasional. Keunggulan dari sektor ini adalah termasuk dalam sumber daya terbarukan sehingga tidak ada kekhawatiran akan terjadi permasalahan yang berhubungan dengan ketersediaannya. Meskipun demikian sektor pariwisata tetap mempunyai kelemahan yaitu sangat mengandalkan kunjungan wisatawan baik dari dalam maupun luar negeri yang mempunyai tingkat sensitifitas tinggi terhadap isu-isu keamaman dan terorisme [1]. Selain itu juga faktor adanya musibah bencana alam sangat mempengaruhi sektor pariwisata ini. Oleh karena itu, koordinasi dari semua elemen dan stakeholder pariwisata serta masyarakat sangat diperlukan untuk menjaga iklim agar tetap aman dan kondusif [2].

Dalam beberapa tahun terakhir sektor pariwisata berhasil menjadi sektor unggulan dalam menyumbang devisa negara. Menurut data dari Kementerian Pariwisata, pada tahun 2016 devisa dari sektor pariwisata mencapai US\$13,568 miliar dan telah berada di posisi kedua setelah devisa dari CPO sebesar US\$15,965 miliar [3]. Diprediksi pada tahun 2018 ini sumbangan dari sektor pariwisata mencapai US\$20 miliar atau naik sekitar $20 \%$ dari tahun 2017 yang sekitar US\$ 16,8 miliar. Menurut data dari Badan Pusat Statistik [4], jumlah kunjungan wisatawan mancanegara sampai Juni 2018 adalah 7,53 juta. Kunjungan meningkat 13,08\% dari jumlah kunjungan pada Juni 2017 yang berjumlah 6,66 juta kunjungan.

Kabupaten Tegal adalah salah satu kabupaten di Provinsi Jawa Tengah yang memiliki topografi wilayah yang lengkap dan bervariatif. Wilayahnya terbentang dari pesisir Laut Jawa hingga ke selatan sampai ke kaki Gunung Slamet. Hal tersebut menjadikan Kabupaten Tegal memiliki banyak destinasi wisata yang sangat bervariatif, mulai dari wisata alam, wisata religi, wisata sejarah hingga wisata budaya [5]. 
Salah satu obyek wisata yang dikenal di Kabupaten Tegal adalah obyek wisata pantai Purwahamba Indah. Obyek wisata ini berada di wilayah Kabupaten Tegal bagian utara tepatnya di Desa Purwahamba Kecamatan Suradadi. Letak obyek wisata ini sangat strategis yaitu di sisi jalan raya Pantai Utara Jawa yang merupakan jalan utama penghubung Pulau Jawa. Letak obyek wisata pantai Purwahamba Indah yang strategis menjadikan obyek wisata ini sebagai primadona destinasi wisata pantai pada awal tahun 2000-an, salah satunya karena memiliki kolam renang yang bertaraf nasional.

Namun dalam beberapa tahun belakangan perkembangan kunjungan wisatawan di obyek wisata pantai Purwahamba Indah cenderung mengalami stagnansi, dapat dilihat pada Tabel 1. Banyak faktor yang menyebabkan fluktuasi jumlah wisatawan ini yaitu, faktor persaingan antar destinasi wisata sejenis yang semakin meningkat, faktor warga masyarakat yang kurang mempunyai rasa kepedulian terhadap keberadaan obyek wisata, dan faktor kurang matangnya perencanaan pariwisata dalam merespon perkembangan zaman serta faktor klasik kurangnya dukungan anggaran dari pemerintah bagi pengembangan infrastuktur wisata.

Tabel 1. Jumlah kunjungan wisatawan obyek wisata pantai Purwahamba Indah tahun 2014-2018 [5-6]

\begin{tabular}{ccc}
\hline No & Tahun & Jumlah Wisatawan (orang) \\
\hline 1 & 2018 & 164.397 \\
2 & 2017 & 191.569 \\
3 & 2016 & 188.052 \\
4 & 2015 & 163.721 \\
5 & 2014 & 149.804 \\
\hline
\end{tabular}

Berdasarkan permasalahan yang telah dijabarkan, dalam pengembangan pantai Purwahamba Indah perlu ditemukenali potensi dan kendala yang dihadapi. Potensi dan kendala merupakan karakter spesifik kawasan yang menjadi dasar untuk menentukan arah konsep pengembangan wisata. Pertanyaan penelitian yang muncul dengan latar belakang permasalahan yang telah dijabarkan adalah bagaimanakan potensi dan kendala pengembangan pengembangan obyek wisata pantai Purwahamba Indah Kabupaten Tegal. Guna menjawab pertanyaan tersebut, maka dilakukan penelitian untuk menemukenali seluruh potensi dan kendala yang terdapat di pantai Purwahamba Indah secara komprehensif. Sudut pandang ini yang membedakan penelitian ini berbeda dengan penelitian-penelitian sebelumnya yang hanya berfokus pada beberapa komponen pendukung pariwisata saja.

\section{Metode penelitian}

Tujuan penelitian ini adalah mengetahui potensi dan kendala yang dihadapi dalam pengembangan obyek wisata pantai Purwahamba Indah Kabupaten Tegal. Pendekatan penelitian yang digunakan adalah pendekatan campuran atau Mixed Method. Pendekatan campuran merupakan pendekatan yang menggabungkan metode kuantitatif dan kualitatif. Penggunaan dua metode ini bertujuan untuk memberikan penjelasan yang lebih 
komprehensif daripada penggunaan salah satu metode tersebut. Pendekatan ini lebih rumit, karena melibatkan dua metode secara bersamaan sehingga penelitian ini lebih lengkap daripada menggunakan salah satu metode saja.

Peneliti menggunakan empat teknik dalam proses pengumpulan data, yaitu teknik wawancara, kuesioner, observasi dan studi literatur. Teknik wawancara dengan sembilan narasumber digunakan untuk mengetahui kendala-kendala yang dihadapi dalam pengembangan obyek wisata pantai Purwahamba Indah Kabupaten Tegal. Teknik kuesioner digunakan dalam rangka mengetahui persepsi pengunjung terhadap aspek yang menjadi kendala dalam pengembangan obyek wisata pantai Purwahamba Indah Kabupaten Tegal. Observasi dilakukan untuk melihat langsung kondisi eksisting obyek wisata pantai Purwahamba Indah Kabupaten Tegal.

Teknik sampling yang digunakan untuk mencari narasumber menggunakan teknik Purposive Sampling yaitu teknik pengambilan sampel sumber data yang didasarkan dengan pertimbangan tertentu [7]. Jumlah narasumber yang dipilih adalah sembilan orang. Data narasumber dapat dilihat pada Tabel 2. Selain sampling narasumber, dalam menganalisis persepsi masyarakat digunakan teknik Simple Random Sampling dengan rumus Slovin [8] dengan jumlah 100 orang.

Tabel 2. Data narasumber penelitian.

\begin{tabular}{cll}
\hline No. & \multicolumn{1}{c}{ Narasumber } & Jumlah \\
\hline 1. & Dinas Pariwisata Pemuda dan Olahraga Kabupaten Tegal & 2 Orang \\
2. & UPTD Obyek Wisata Purwahamba Indah & 2 Orang \\
3. & Pedagang & 2 Orang \\
4. & Pengelola parkir & 1 Orang \\
5. & Masyarakat sekitar & 2 Orang \\
\hline
\end{tabular}

Metode analisis yang digunakan adalah metode delphi yang ditunjang dengan metode deskriptif kualitatif dan analisis statistik deskriptif. Metode delphi adalah teknik untuk menebak pendapat yang bersifat kualitatif berdasarkan cara pandang ahli yang menjadi narasumber. Teknik analisis deskriptif kualitatif adalah metode yang bertujuan untuk mendapatkan pemahaman yang sifatnya umum terhadap kenyataan sosial dari perspektif partisipan [9].

Teknik analisis deskriptif kualitatif digunakan untuk menganalisis hasil wawancara dan dideskripsikan untuk mendapatkan gambaran, pandangan dan penilaian atas hal-hal yang menjadi kendala dalam pengembangan obyek wisata pantai Purwahamba Indah Kabupaten Tegal. Teknik analisis statistik deskriptif adalah teknik statistik yang berguna untuk memberikan deskripsi data yang diperoleh dari kuesioner terhadap warga masyarakat. 


\section{Pembahasan}

\subsection{Gambaran umum pantai Purwahamba Indah}

Pantai Purwahamba Indah terletak di Desa Purwahamba Kecamatan Suradadi Kabupaten Tegal. Pantai ini terletak di pesisir Laut Jawa. Seperti pantai-pantai yang terletak di utara Pulau Jawa, pantai Purwahamba Indah ini memiliki ombak yang sedang-sedang saja, terkadang sangat tenang namun terkadang besar ketika musim angin tiba. Pantai Purwahamba Indah berjarak $14 \mathrm{~km}$ arah timur Kota Tegal, posisinya yang sangat strategis tepat berada di sisi jalan Pantai Utara Jawa menjadikan pantai ini sangat cocok sebagai tempat istirahat dan melepas lelah bagi para pengguna jalan pantura yang sedang melintas.

Pantai Purwahamba Indah ini menawarkan beberapa macam keindahan alam dan wahana yang menarik untuk dikunjungi. Pengunjung dapat menikmati pemandangan pantai yang indah beserta ombak pantai yang tenang di tepi pantai yang dilengkapi dengan deretan saung-saung sebagai tempat bersantai para pengunjung, dapat dilihat pada Gambar 1 . Selain itu pantai Purwahamba Indah juga menyediakan banyak wahana permainan anak sehingga sangat sesuai untuk dijadikan wisata keluarga. Salah satunya adalah wahana dirgantara yang dilengkapi dengan adanya pesawat terbang Boeing 737 dimana pengunjung dapat menikmati film tiga dimensi di dalamnya, dapat dilihat pada Gambar 3.

Pantai Purwahamba Indah juga memiliki fasilitas berupa kolam renang yang sudah berstandar nasional dengan water boom mini yang menambah lengkap wahana air yang tersedia, dapat dilihat pada Gambar 2. Terdapat pula sebuah ruang pertemuan dengan konsep bangunan terbuka sehingga dapat dimanfaatkan sambil menikmati suasana pantai, dapat dilihat pada Gambar 3. Fasilitas tempat parkir yang cukup luas dan representatif juga tersedia bagi para pengunjung yang membawa kendaraan pribadi ataupun kendaraan umum. Pantai Purwahamba Indah juga banyak menyediakan kuliner khas pesisir seperti ikan bakar, ikan goreng dan ayam goreng khas Tegal dan suguhan kelapa muda yang banyak tersedia di warung sepanjang pantai Purwahamba Indah.
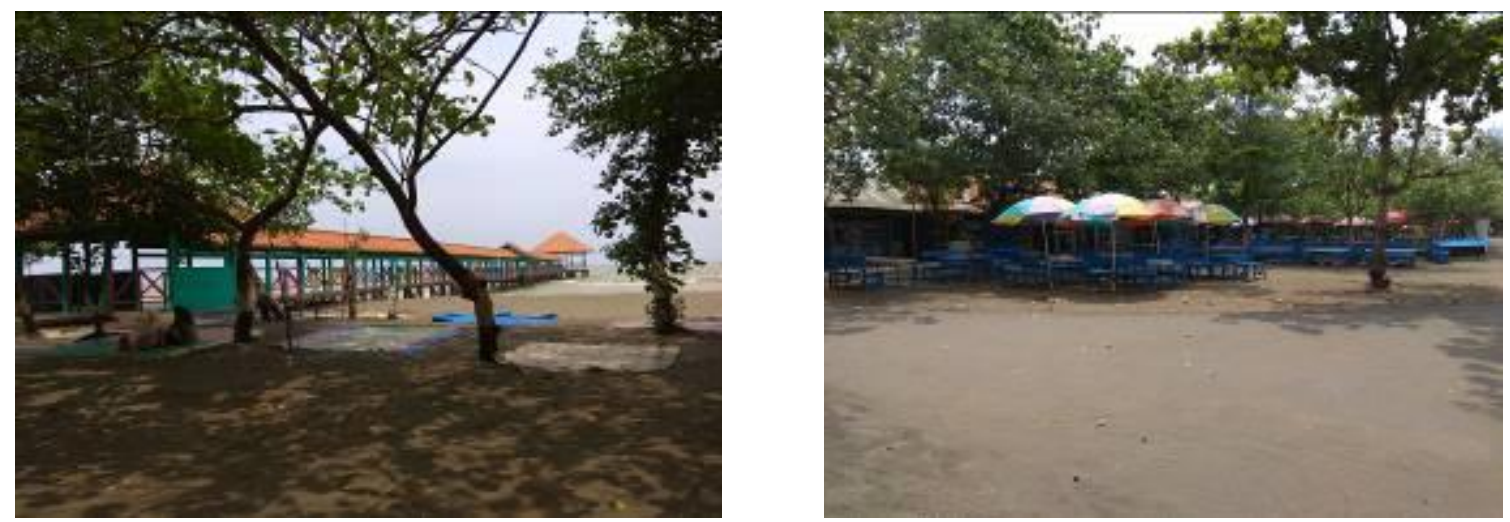

Gambar 1. Suasana tepi pantai dan tempat istirahat. 

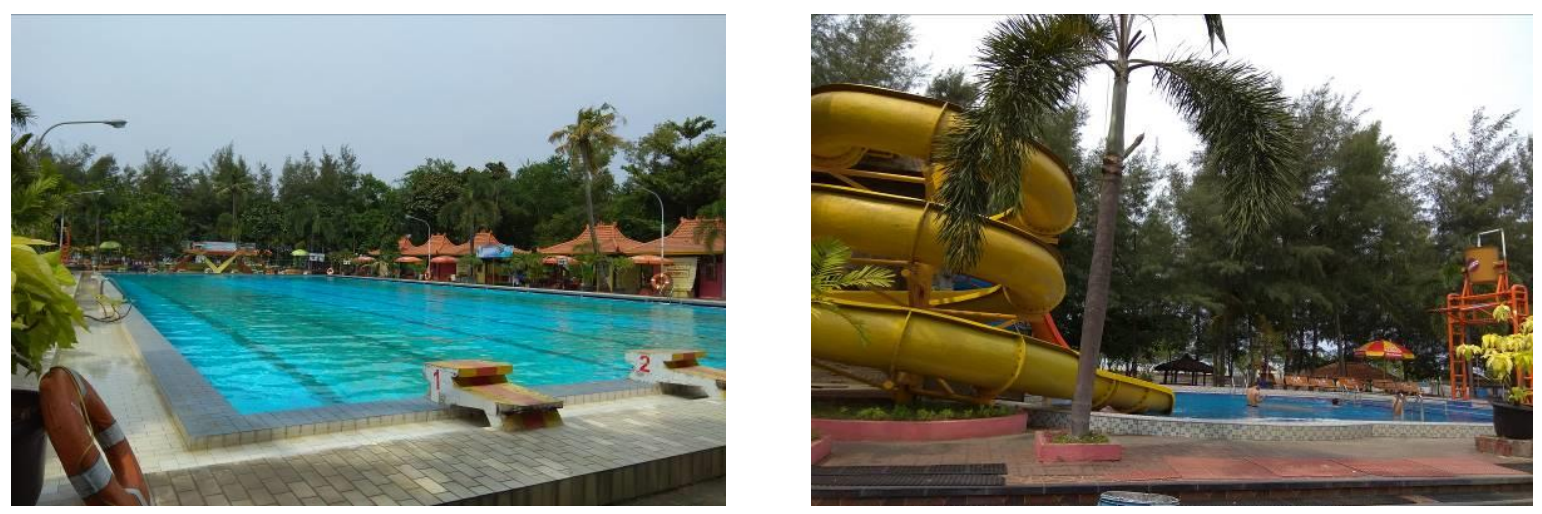

Gambar 2. Kolam renang dan water boom mini.
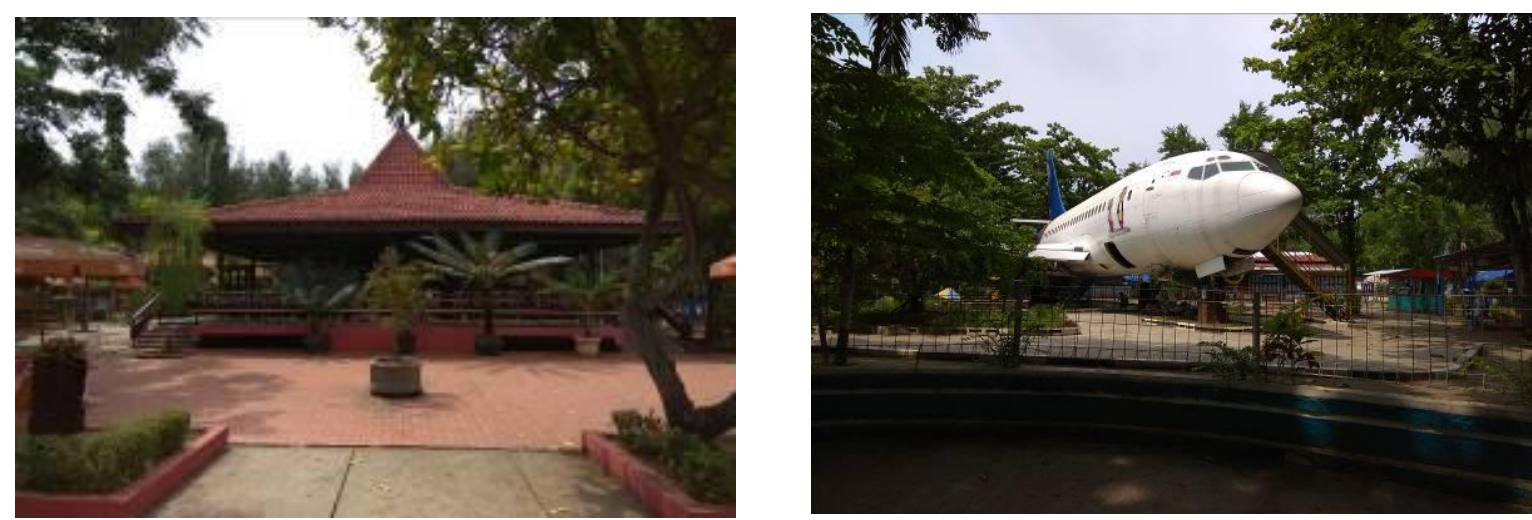

Gambar 3. Ruang pertemuan dan wahana dirgantara.

\subsection{Kendala pengembangan pantai Purwahamba Indah}

Banyak hal yang menjadikan kendala dalam pengembangan obyek wisata pantai Purwahamba Indah antara lain:

1. Keterbatasan anggaran dari Pemerintah Daerah Kabupaten Tegal

2. Terbatasnya sumber daya manusia yang dapat melihat potensi pariwisata dengan jeli

3. Belum adanya sinergitas stakehoder yang ada

4. Belum adanya pola promosi dan pemasaran yang efektif dalam meningkatkan arus pengunjung

5. Adanya persaingan obyek wisata sejenis yang semakin ketat

\subsection{Konsep pengembangan pantai Purwahamba Indah}

Konsep pengembangan obyek wisata pantai Purwahamba Indah tidak lepas dari dukungan sarana dan prasarana yang ada. Secara ideal suatu obyek wisata agar dapat menjadi destinasi unggulan harus memenuhi standar minimal daerah tujuan wisata. Beberapa contoh kriteria sarana dan prasarana wisata yang harus tersedia diantaranya:

3.3.1. Sarana wisata. Sarana wisata didefinisikan sebagai kelengkapan daerah destinasi wisata yang diperlukan untuk melayani segala kebutuhan pengunjung [10]. Pengadaan sarana wisata di suatu obyek wisata harus disesuaikan dengan karakteristik obyek wisata 
tersebut dan kebutuhan serta selera pengunjung destinasi wisata tersebut. Di dalam kepariwisataan dikenal tiga jenis sarana wisata yaitu:

1. Sarana pokok kepariwisataan

Sarana pokok kepariwisataan merupakan perusahaan yang menyediakan fasilitas pokok pariwisata. Contohnya adalah travel agent, tour operator, hotel dan tempat penginapan, restoran dan tempat makan.

2. Sarana pendukung/pelengkap kepariwisataan

Sarana pendukung kepariwisataan merupakan perusahaan yang fungsinya melengkapi sarana pokok kepariwisataan [10]. Contohnya toko pakaian, perhiasan dan sarana olahraga dan kebugaran.

3. Sarana penunjang kepariwisataan

Sarana penunjang kepariwisataan adalah perusahaan yang menunjang sarana pelengkap dan pokok kepariwisataan. Sarana penunjang kepariwisataan ini berfungsi agar wisatawan bertahan lebih lama dan mengeluarkan lebih banyak uang di tempat wisata. Contohnya adalah sarana atraksi wisata dan karaoke.

3.3.2. Prasarana wisata. Prasarana wisata adalah sumber daya yang dibutuhkan oleh wisatawan dalam perjalanannya menuju obyek wisata seperti jalan, listrik, air, telekomunikasi, terminal, jembatan dan lain sebagainya [10]. Ada beberapa prasarana pariwisata yaitu:

1. Receptive tourist plant

Badan usaha atau organisasi yang berfungsi untuk mempersiapkan kedatangan wisatawan.

2. Residental tourist plant

Tempat yang digunakan wisatawan untuk tinggal sementara waktu di tempat wisata.

3. Recretive and sportive plant

Fasilitas yang dapat digunakan untuk berolahraga dan bersenang-senang.

\subsection{Analisis faktor yang menjadi kendala pengembangan pantai Purwahamba Indah}

Berdasarkan analisis yang dilakukan dengan metode delphi, narasumber berpendapat bahwa ada lima faktor yang menjadi kendala dalam pengembangan obyek wisata pantai Purwahamba Indah yaitu faktor dukungan anggaran, perencanaan, dukungan masyarakat sekitar, komitmen pemerintah dan faktor pemasaran. Dapat dilihat pada Tabel 3.

Kurangnya dukungan anggaran Pemerintah Daerah Kabupaten Tegal menyebabkan wahana wisata yang tersedia menjadi kurang bervariatif dan kurang menarik. Padahal dukungan anggaran tidak harus berasal dari anggaran pemerintah saja akan tetapi pihak swasta dapat pula ikut serta dalam menyediakan investasi untuk meningkatkan infrastruktur wisata. Selain itu faktor perencanaan sektor pariwisata Kabupaten Tegal yang masih lemah ditandai dengan belum adanya Rencana Induk Pariwisata Daerah. Implikasinya adalah konsep pengembangan obyek wisata pantai Purwahamba Indah menjadi tidak terarah. Hal inilah yang menyebabkan investor menjadi kebingungan untuk berinvestasi. 
Faktor lainnya yang tidak kalah penting adalah sikap dan perilaku masyarakat sekitar obyek wisata yang ikut berpartisipasi di obyek wisata seperti dalam pengelolaan parkir, berjualan aneka macam suvenir dan kuliner serta wahana permainan anak. Ketika perilaku dan sikap mereka justru berjalan kearah kontraproduktif terhadap pengelolaan wisata maka obyek wisata itu berjalan menuju kemunduran. Beberapa sikap kontraproduktif yang sering dijumpai adalah sikap kurang ramah, memasang tarif parkir yang terlalu mahal serta harga makanan dan minuman yang dijajakan terlalu tinggi bagi pengunjung.

Kesadaran masyarakat sekitar untuk ikut serta menjaga dan mengembangkan obyek wisata penting untuk terus ditumbuhkan. Pemerintah daerah berupaya meningkatkan partisipasi masyarakat melalui program pembentukan kelompok sadar wisata atau pokdarwis yang terdiri dari pemuda atau pemudi masyarakat sekitar yang sudah dibekali ilmu dan pengalaman untuk ikut serta dalam pengembangan obyek wisata di lingkungannya. Obyek wisata pantai Purwahamba Indah sudah memiliki kelompok sadar wisata atau pokdarwis, akan tetapi karena keterbatasan pendanaan sehingga belum banyak kegiatan yang dapat dilaksanakan untuk kemajuan obyek wisata.

Di era globalisasi ini, perkembangan teknologi informasi semakin pesat. Salah satunya ditandai dengan munculnya berbagai jenis sosial media seperti instagram, twitter, facebook dan lain-lain. Keberadaan sosial media ini ikut mempengaruhi kegiatan promosi obyek wisata. Namun dibalik kemudahan proses promosi tersebut, diperlukan sumber daya manusia yang memiliki daya kreatifitas yang cukup tinggi. Hal inilah yang belum dimiliki oleh pemerintah daerah sehingga proses promosi menjadi kurang efektif. Disamping proses promosi, peran travel agent sebagai pihak yang ikut menentukan besaran kunjungan wisatawan juga belum bekerja dengan aktif. Hal ini bisa dilihat pada daerah asal pengunjung obyek wisata pantai Purwahamba Indah yang rata-rata berasal dari derah sekitar Kabupaten Tegal.

Berdasarkan banyaknya kendala yang dihadapi dalam pengembangan kembali obyek wisata pantai Purwahamba Indah, sudah menjadi kewajiban bagi pemerintah daerah dalam hal ini Dinas Pariwisata Pemuda dan Olahraga Kabupaten Tegal agar lebih fokus dan komprehensif dalam mengembangkan obyek wisata ini.

Tabel 3. Kendala dalam pengembangan obyek wisata pantai Purwahamba Indah berdasarkan metode delphi.

\begin{tabular}{|c|c|c|}
\hline No & Faktor & Kendala \\
\hline 1. & Dukungan Anggaran & $\begin{array}{l}\text { 1. Minimnya anggaran yang tersedia di sektor pariwisata } \\
\text { untuk pembangunan sarana dan prasarana dan } \\
\text { peningkatan kapasitas sumber daya manusia serta } \\
\text { peningkatan kesadaran wisata masyarakat sekitar }\end{array}$ \\
\hline 2. & Perencanaan & $\begin{array}{l}\text { 1. Belum adanya sinergitas dan integrasi antara program } \\
\text { dan potensi obyek wisata dan masyarakat sekitar. } \\
\text { 2. Belum jelasnya skenario pengembangan obyek wisata } \\
\text { pantai Purwahamba Indah ke depannya }\end{array}$ \\
\hline
\end{tabular}




\begin{tabular}{|c|c|c|}
\hline & Faktor & Kendala \\
\hline & $\begin{array}{l}\text { Sikap dan Perilaku } \\
\text { Masyarakat }\end{array}$ & $\begin{array}{l}\text { 1. Sikap dan perilaku masyarakat sekitar yang belum } \\
\text { dapat memberikan pelayanan yang terbaik terhadap } \\
\text { pengunjung. } \\
\text { 2. Kurangnya kesadaran masyarakat untuk mengelola } \\
\text { tempat pariwisata di wilayahnya sehingga cenderung } \\
\text { bersikap acuh salah satunya dalam menjaga kebersihan } \\
\text { obyek wisata. }\end{array}$ \\
\hline 4. & Komitmen Pemerintah & $\begin{array}{l}\text { 1. Kurangnya keterlibatan pemerintah daerah dalam } \\
\text { mengembangkan potensi yang ada } \\
\text { 2. Pemerintah daerah kurang berperan aktif dalam upaya } \\
\text { menyadarkan masyarakat sekitar }\end{array}$ \\
\hline 5. & Pemasaran & $\begin{array}{l}\text { 1. Kurang aktifnya partisipasi travel agent pariwisata } \\
\text { 2. Promosi yang kurang efektif }\end{array}$ \\
\hline
\end{tabular}

\section{Kesimpulan}

Berdasarkan penelitian yang dilakukan penulis, ada lima faktor yang menyebabkan kurang optimalnya pengembangan obyek wisata pantai Purwahamba Indah Kabupaten Tegal. Pertama dukungan anggaran yang kurang, selama ini hanya mengandalkan anggaran dari pemerintah daerah yang sangat terbatas, padahal potensi dari investasi swasta bisa menjadi solusi untuk menyelesaikan permasalahan anggaran. Faktor perencanaan yang belum jelas sebagai determinan kedua. Belum adanya skenario pengembangan pantai Purwahamba Indah ke depan dan sinergi antara program kegiatan dan potensi wisata masyarakat yang ada menyebabkan pengembangan obyek wisata pantai Purwahamba Indah menjadi tidak terarah. Kurangnya kesadaran masyarakat sekitar dalam menjaga kebersihan lingkungan obyek wisata serta perilaku mereka yang belum bisa memberikan pelayanan yang baik terhadap pengunjung menyebabkan pengunjung enggan untuk berwisata kembali. Faktor inilah yang menjadi determinan ketiga pada kendala pengembangan obyek wisata pantai Purwahamba Indah. Selain itu faktor kurangnya komitmen pemerintah dalam menumbuhkan kesadaran masyarakat terhadap keberadaan obyek wisata pantai Purwahamba Indah menjadi faktor keempat kendala pengembangan obyek wisata pantai Purwahamba Indah. Faktor kelima adalah kurang efektifnya promosi dan keberadaan travel agent sehingga tingkat kunjungan wisatawan menjadi kurang optimal.

\section{Ucapan terima kasih}

Puji dan syukur penulis panjatkan kehadirat Allah SWT atas karunia dan nikmatNya, sehingga penulis dapat menyelesaikan penelitian ini. Penulis juga mengucapkan terima kasih kepada Dr. Ir. Joesron Alie Syahbana, M.SP selaku dosen mata kuliah Perencanaan Tata Ruang dan Lingkungan Magister Ilmu Lingkungan Universitas Diponegoro dan semua pihak yang telah membantu penulis untuk menyelesaikan penelitian ini.

\section{Referensi}

[1] Indiarto W 2009 Dampak Terorisme terhadap Industri Pariwisata dan Upaya Penanggulangannya di Indonesia: Studi Kasus Di Wilayah Dinas Pariwisata Jakarta Tesis (Yogyakarta: Universitas Gadjah Mada) 
[2] Aliperti G, Rizzi F, dan Frey M 2018 Cause-related Marketing for Disaster Risk Reduction in the Tourism Industry: A Comparative Analysis of Prevention and Recovery-Related Campaigns Journal of Hospitality and Tourism Management 37 110 DOI: 10.1016/j.jhtm.2018.08.003

[3] Chandra A A dan Damarjati D 2017 Tiga Tahun Jokowi-JK, Pariwisata Sumbang Devisa Terbesar Kedua Diakses dari https://finance.detik.com/berita-ekonomi-bisnis/d3687715/tiga-tahun-jokowi-jk-pariwisata-sumbang-devisa-terbesar-kedua pada 0701-2019

[4] Badan Pusat Statistik 2018 Perkembangan Pariwisata dan Transportasi Nasional Juni 2018 Diakses dari https://www.bps.go.id/pressrelease/2018/08/01/1474/jumlahkunjungan-wisman-ke-indonesia-juni-2018-mencapai-1-32-juta-kunjungan.html pada 07-01-2020

[5] Badan Pusat Statistik 2019 Data Wisatawan Yang Masuk Obyek Wisata Purwahamba Indah, 2018 Pemerintah Kabupaten Tegal Diakses dari https://tegalkab.bps.go.id/statictable/2015/01/23/126/data-wisatawan-yangmasuk-obyek-wisata-Purwahamba-indah-2016.html pada 07-01-2020

[6] Badan Pusat Statistik Kabupaten Tegal Dalam Angka 2018 Pemerintah Kabupaten Tegal Diakses dari https://tegalkab.bps.go.id/publication/2018/08/16/7b77ee41dc06c39a3982e568/k abupaten-tegal-dalam-angka-2018.html pada 07-01-2020

[7] Sugiyono 2013 Metode Peneltian Manajemen (Bandung: Alfabeta)

[8] Sarwono J 2013 Strategi Melakukan Riset Kuantitatif, Kualitatif, Gabungan (Yogyakarta: Andi Offset)

[9] Afifudin dan Beni A S 2009 Metode Penelitian Kualitatif (Bandung: Pustaka Setia)

[10] Suwantoro G 2013 Dasar-Dasar Pariwisata (Yogyakarta: Andi) 